\title{
Strategi Bisnis Business Model Canvas pada Bumdes-Mart Berkah
}

\section{Canvas Model Business Strategy on Bumdes-Mart Berkah}

\author{
Agung Prawijaya, R. Hamdani Harahap* \& Erika Revida \\ Magister Perencanaan Pembangunan Wilayah Dan Pedesaan, Sekolah Pascasarjana, \\ Universitas Sumatera Utara, Indonesia
}

Diterima: 09 Juli 2021; Disetujui: 15 Desember 2021; Dipublish: 01 Januari 2022

\begin{abstract}
Abstrak
Tujuan dari penelitian ini untuk melihat pengembangan pasar modern dengan konsep waralaba serta bekerjasama dengan pihak ketiga dalam membuka ruang kemitraan dalam pengelolaan toko usaha desa yang dilakukan oleh para pengelola BUMDes. Menganalisis penerapan strategi bisnis yang dikembangakan oleh BUMDes-Mart Berkah Desa Jatimulyo Kecamatan Pegajahan Kabupaten Serdang Bedagai, menggunakan Business Model Canvas sebagai alat untuk mengindentifikasinya bisnis model yang ada. Penelitian ini menggunakan metode penelitian deskriptif kualitatif, teknik pengumpulan data yaitu dengan melakukan studi kepustakaan dan penelitian di lapangan. Analisis data dilakukan dengan pengumpulan data, mereduksi data, menyajikan data dan menarik kesimpulan. Hasil yang didapat berupa gambaran sembilan elemen pada Business Model yang terdiri atas Customer Segment, Value Propotion, Customer Relationship, Customer Segment, Chanels, Revenue Stream, Cost Structure, Key Activities, Key Resource, dan Key Partners. Model bisnis ini akan mengetahui kelemahan dan kelebihan dari sebuah bisnis yang dijalankan serta untuk mengetahui strategi apa yang bisa dijalankan kedepannya. Selain aspek tersebut, temuan dalam penelitian ini adalah adannya faktor-faktor yang mempengaruhi business model canvas pada BUMDes-Mart yakni dari segi segmen pasar dan finansial.
\end{abstract}

Kata Kunci: BUMDes-Mart; Model Bisnis; Business Model Canvas

\section{Abstract}

The purpose of this study was to see modern market development with the Franchise concept and in collaboration with third parties opens a partnership space in the management of Village Business Stores carried out by BUMDes managers. This study aims to analyze the implementation of the business strategy developed by BUMDes-Mart Berkah Jatimulyo Village, Pegajahan District, Serdang Bedagai Regency, using the business model canvas as a tool to identify existing business models. This research uses descriptive qualitative research methods, data collection techniques by conducting literature studies and research in the field. Data analysis was carried out by collecting data, reducing data, presenting data and drawing conclusions. The results obtained are in the form of a description of the nine elements in the business model consisting of customer segments, value proposition, customer relationships, customer segments, channels, revenue streams, cost structure, key activities, key resources, key partners. This business model will find out the weaknesses and strengths of a business that is being run and to find out what strategies can be implemented in the future. In addition to these aspects, the findings in this study are that there are factors that influence the business model canvas on BUMDes-Mart, namely in terms of market and financial segments.

Kata Kunci: BUMDES-Mart; Canvas Model; Business Strategy

How to Cite: Prawijaya, A., Harahap, R.H., \& Revida, E., (2022). strategi bisnis business model canvas pada Bumdes-mart berkah. PERSPEKTIF, 11 (2): 169-178 


\section{PENDAHULUAN}

Pembangunan merupakan upaya untuk meningkatkan kesejahteraan seluruh kehidupan masyarakat, bangsa, dan negara dalam mewujudkan tujuan nasional yang tercantum pada Pembukaan UUD 1945. Desa memiliki peranan penting dalam upaya pembangunan nasional dikarenakan penduduk Indonesia cenderung bermukim di wilayah pedesaan sehingga hal tersebut memberikan pengaruh dan dampak yang cukup besar dalam upaya penciptaan stabilitas nasional.

Pengembangan basis ekonomi perdesaan diharapkan mendorong dan menggerakkan roda perekonomian perdesaan ialah pendirian kelembagaan ekonomi yang dikelola penuh masyarakat desa. Lembaga ekonomi ini tidak lagi didirikan menurut instruksi pemerintah tetapi keinginan masyarakat desa, mulai dari pengelolaan potensi akan menimbulkan permintaan pasar sampai pada dampak dan manfaatnya yang dirasakan oleh masyarakat Desa. Agar keberadaan lembaga ekonomi ini tidak dikuasai oleh kelompok tertentu yang memiliki modal besar di perdesaan, maka kepemilikan lembaga itu oleh desa dikontrol di mana tujuan utamanya untuk meningkatkan standar hidup ekonomi masyarakat.

Landasan hukum yang melandasi berdirinya Badan Usalah Milik Desa (BUMDes) ini antara lain adalah Undang-Undang No. 6 Tahun 2014 Tentang Desa, serta Peraturan Pemerintah No. 43 Tahun 2014 Tentang Peraturan Pelaksanaan Undang-Undang No. 6 Tahun 2014 Tentang Desa. Untuk melaksanakan ketentuan tersebut perlu menetapkan Peraturan Menteri Desa, Pembangunan Daerah Tertinggal, dan Transmigrasi No. 4 Tahun 2015 Tentang pendirian, pengurusan dan pengelolaan, dan pembubaran Badan Usaha Milik Desa (BUMDes). Pendirian BUMDes harus disepakati melalui Musyawarah Desa, agar terciptanya akuntabilitas dan transparansi. Tidak ada lagi BUMDes yang berdiri karena program atau proyek pemerintah Desa dan kejelasan kepemilikan BUMDes menjadi tanda tanya bagi pemerintah Desa. Sedangkan maksud dari pendirian BUMDes tersebut adalah sebagai upaya menampung seluruh kegiatan di bidang ekonomi dan/atau pelayanan umum yang dikelola oleh Desa dan/atau kerja sama antarDesa. Memulai dan mengembangkan bisnis atau usaha yang ada di dalam BUMDes memang membutuhkan perencanaan dan keberanian tetapi juga membutuhkan perhitungan bisnis secara matang, sehingga resiko bisnis yang muncul dapat dikelola dengan baik secara profesional oleh BUMDes, didalam Peraturan Pemerintah No. 11 Tahun 2021 Tentang Badan Usaha Milik Desa yang menjelaskan bahwa profesional adalah tata kelola yang dilaksanakan sesuai dengan kaidah yang ada dan dikerjakan oleh pelaku yang memiliki kemampuan dan kompetensi yang memadai.

Sedangkan tujuan dari pendirian BUMDes adalah sebagai upaya ; Meningkatkan perekonomian Desa; Mengoptimalkan aset Desa agar be rmanfaat untuk kesejahteraan Desa; Meningkatkan usaha masyarakat dalam pengelolaan potensi ekonomi Desa; Mengembangkan rencana kerja sama usaha antar desa dan/atau dengan pihak ketiga; Menciptakan peluang dan jaringan pasar yang mendukung kebutuhan layanan umum warga; Membuka lapangan kerja; Meningkatkan kesejahteraan masyarakat melalui perbaikan pelayanan umum, pertumbuhan dan pemerataan ekonomi Desa; dan meningkatkan pendapatan masyarakat Desa dan Pendapatan Asli Desa.

Merujuk perkataan Presiden RI Jokowi pada saat rapat terbatas yaitu "Penggunaan Dana Desa harus mulai diarahakan kepada sektor-sektor produktif. Mulai dari pengolahan pascapanen, industri kecil di desa, budidaya perikanan, desa wisata, dan industrilisasi pedesaan juga harus sudah dimulai karena ini penciptaan lapangan kerja besar-besaran. BUMDes harus revitalisasi jadi penggerak ekonomi di desa" (Setkab, Rabu 11/12/19). dengan adanya kehadiran BUMDes-Mart Berkah ini juga bisa membuka lapangan pekerjaan selain membuat desa kearah yang lebih produktif sesuai apa yang disampaikan oleh Bapak Presiden RI Jokowi.

Siagian (2008), pembangunan adalah suatu usaha atau rangkaian usaha pertumbuhan dan perubahan yang terencana yang dilakukan secara sadar oleh suatu bangsa, negara dan pemerintah menuju modernitas dalam rangka pembinaan bangsa (nation building). suatu usaha serangkaian usaha pertumbuhan dan perubahan yang berencana yang dilakukan secara sadar oleh suatu bangsa, negara dan pemerintahan dalam usaha bangsa

Terobosan yang sangat strategis dalam bisnis ini adalah jika usaha ini dilakukan oleh 
sekelompok orang atau warga masyarakat yang terhimpun dalam suatu organisasi dimana lebih baik lagi jika perhimpunan, perkumpulan atau kelompok itu hidup dalam satu area yang sama seperti hal Desa, maka hal ini menjadi salah satu pendukung pendirian BUMDes-Mart Berkah dimana BUMDes adalah suatu lembaga yang paling strategis mengembangkan usaha minimarket.

Sentosa (2017) menjelaskan bahwa Hal yang harus diperhatikan oleh Pemerintah Desa jika mendirikan BUMDes harus mengetahui bidang usaha apa yang menjadi keunggulan di Desa tersebut. Selain itu harus juga dipersiapkan para pengelola yang bersedia secara penuh waktu untuk mengelola BUMDes. Senada yang dilakukan oleh peneliti Ramadana (2013) menjelaskan bahwa Keberadaan Badan Usaha Milik Desa yang ada di Desa sebagai penguatan ekonomi Desa

BUMDes-Mart Berkah membutuhkan captive market alias segmen pasar yang jelas alias kelompok orang yang dibidik sebagai para calon pembeli itu bakal lebih mudah didapatkan jika mereka berada di satu area yang mudah menjangkau minimarket ini. dan jangan heran jika jaringan minimarket yang berhasil pada umumnya karena berada di tempat yang gampang dijangkau dan memiliki bangunan yang mempunyai akses baik diluar maupun dalamnya, termasuk dilengkapi fasilitas alat pendingin udara. Serta adanya relasi dengan konsumen dan perlunya kolektifitas bersama, inilah yang membuat minimarket milik BUMDes atau BUMDes-Mart, harus memiliki keunggulan yang tak akan bisa disaingi perusahaan swasta, karena BUMDesMart Berkah adalah milik warga desa dan bukan milik perseorangan, kepemilikan bersama adalah sebuah modal sosial yang menjadi potensi awal BUMDes-Mart Berkah.

Kehadiran BUMDes-Mart Berkah Desa Jatimulyo ini diharapkan dapat meningkatkan Pendapatan Asli Desa (PAD). Tetapi mengingat BUMDes-Mart Berkah Desa Jatimulyo masih termasuk hal yang baru dalam keberadaannya, maka tidak heran di dalam prakteknya masih ada beberapa kendala yang muncul terutama dalam segi pembentukan dan pengelolaan. Walaupun sebenarnya sudah tertanam semangat untuk melembagakan Badan Usaha Milik Desa (BUMDes) telah diamanatkan dan dipayungi dengan Undang-Undang No. 32 Tahun 2004 Jo. Undang-Undang No. 23 Tahun
2014 Tentang Pemerintah Daerah pada Pasal 213 ayat (1) disebutkan bahwa," Desa dapat mendirikan Badan Usaha Milik Desa (BUMDes) sesuai dengan kebutuhan dan potensi Desa". Dengan harapan dapat meningkatkan pendapatan masyarakat dan pendapatan Desa yang akhirnya berdampak positif terhadap kesejahteraan masyarakat Desa Jatimulyo.

Di sisi lain perkembangan didalam dunia bisnis sendiri memiliki daya tarik yang membuat beberapa ahli baik dari kalangan praktisi maupun akademisi menaruh perhatian khusus untuk mengembangkan model guna mempermudah pelaku bisnis dalam menjalankan bisnisnya. Banyak sekali kalangan akademisi maupun praktisi yang telah mernbuat sistem yang dapat digunakan untuk menjalankan kegiatan bisnis usaha. Beberapa diantaranya adalah penasihat untuk topik model bisnis inovatif, Dr. Alex Osterwalder dengan Dr. Yves Pigneur yang merupakan seorang profesor bidang Sistem Informasi Manajemen di Universitas Lausanne, Swiss beserta beberapa orang dalam timnya telah membuat sebuah model bisnis. Model bisnis yang sangat terkenal yang pernah mereka buat adalah Business Model Canvas.

Osterwalder dan Pigneur (2010) dalam bukunya yang berjudul "Business Model Generation" mengatakan bahwa sebuah model bisnis menggambarkan dasar pemikiran tentang bagaimana organisasi menciptakan, memberikan dan menangkap nilai. Dapat dikatakan bahwa sebenarnya sebuah organisasi bisnis membutuhkan sebuah model untuk membantu organisasi tersebut agar dapat menciptakan, memberikan dan menangkap nilai yang berkaitan dengan aktivitas organisasi tersebut dan tidak terkecuali dalam Badan Usaha Milik Desa (BUMDes).

Biasanya saat seseorang baru mengetahui tentang Business Model Canvas, orang tersebut akan berfikir bahwa model ini sama dengan Business Plan atau perencanaan bisnis. Padahal Business Model Canvas dan Business Plan adalah dua cara yang berbeda dalam mengambil sudut pandang terhadap bisnis. Business Model Canvas dapat dikatakan sebagai sebuah kacamata yang jika digunakan untuk melihat sebuah bisnis, maka bisnis tersebut akan terlihat lebih sederhana dari sebelumnya. 


\begin{abstract}
Menggunakan Business Model Canvas kelima konsentrasi tersebut akan disederhanakan kedalam beberapa balok bangun dalam model ini. Business Model Canvas dapat digunakan untuk bisnis kecil maupun besar, untuk bisnis yang sedang berjalan atau bisnis yang akan dibangun. Model ini sudah teruji dan sangat mudah dipelajari sehingga akan sangat mudah memetakan sebuah bisnis jika kita sudah mengerti tentang model ini. Berbeda dengan Business Plan yang seharusnya masih memposisikan bisnis pada tahap perencanaan yang berarti bisnis yang dibahas belum berjalan atau belum terlaksana. Meskipun, baik dari Business Model Canvas maupun Business plan dapat berfungsi sebagai alat memetakan suatu bisnis usaha, Business Model Canvas memiliki keunggulan lebih dibandingkan dengan Business Plan.
\end{abstract}

Osterwalder dan Pigneur (2010) mengatakan bahwa dalam memetakan suatu bisnis atau usaha dengan menggunakan Business Model Canvas adalah menggambarkan bisnis usaha kita kedalam sembilan konten atau sembilan balok bangun dasar. Model bisnis dapat dijelaskan dengan sangat baik melalui sembilan balok bangun dasar tersebut yang memperlihatkan cara berfikir tentang bagaimana cara untuk menghasilkan uang. Dalam susunan sembilan balok bangun tersebutlah yang disebut dengan Business Model Canvas. Business Model Canvas terbagi menjadi sembilan bagian utama, yaitu: Customer Segments (Segmen Pasar), Value Propositions (Proposisi Nilai), Channel (Cara menjangkau konsumen), Customer Relationships (Hubungan Konsumen), Revenue Streams (Aliran Pendapatan), Key Resources (Sumber Daya Utama), Key Activities (Aktifitas Utama), Key Partnerships (Jaringan Pemasok dan rekanan) dan Cost Struktur (Struktur Biaya). Kemudian bagian-bagian ini dibagi lagi pada dua sisi yaitu sisi kiri (logika) dan sisi kanan (kreatifitas).

Dalam perkembangan bisnis usaha saat ini, ditemui banyak sekali bentuk dan jenis usahanya. Bahkan beberapa bentuk dan jenis bisnis usaha tersebut memiliki persamaan seperti produk yang sama sehingga membuat beberapa bisnis usaha harus bersaing untuk mendapatkan konsumen sebanyak-banyaknya. Maka cara yang paling efektif untuk memenangkan hati konsumen adalah dengan memberikan kepuasan terhadap konsumen dan kepuasaan konsumen akan tercapai jika perusahaan dapat memenuhi kebutuhan konsumen terhadap sesuatu. Inilah penting sebuah Value Propositions atau Proposisi Nilai bagi konsumen. Pada titik inilah bisnis usaha akan berlomba memberikan nilai terbaik kepada konsumen. Pambudi (2015) dan Saputra (2016) mengatakan bahwa Business Model Canvas dapat digunakan dengan baik oleh bisnis ritel, menandakan bahwa Business Model Canvas dapat diterapkan di berbagai jenis usaha. Dan menjadi alternatif untuk menuju finansial yang sehat. Putri (2015) menyatakan penggunaan pendekatan BMC dapat memberikan peluang usaha yang lebih besar untuk pengembangan usaha dengan analisis SWOT pengusaha dapat mengetahui ancaman yang dihadapi. Adapun Penelitian ini bertujuan untuk menganalisis penerapan strategi bisnis Bussines Model Canvas pada BUMDes-Mart Berkah di Desa Jatimulyo Kecamatan Pegajahan Kabupaten Serdang Bedagai.

Business Model Canvas dapat digunakan sebagai pendekatan untuk menciptakan strategi pengembangan bisnis. Model business yang baik selalu memperhatikan tentang nilai pelanggan, hubungan pelanggan, segmen pelanggan, serta selalu mengedepankan penerapan teknologi yang lebih modern untuk menciptakan kepuasan kepada pelanggan, Stefan dan Richard (2014).

Dengan menggunakan Business Model Canvas pengelola akan menemukan jawaban atas segala kebutuhan konsumen yang menjadi segmennya. Nilai yang ditawarkan harus berbeda dan lebih memberi kepuasan terhadap konsumen jika BUMDes-Mart ingin unggul dalam bersaing dengan yang lain. BUMDesMart akan dapat kita lihat sehat atau tidaknya dengan melihat laporan keuangan dari bisnis usaha tersebut. Sehat tidaknya bisnis usaha tersebut dapat menjadi penilaian apakah layak untuk terus dilanjutkan atau tidak. Dalam Business Model Canvas terdapat dua balok yang membahas tentang keuangan dalam bisnis tersebut. Dua balok tersebut adalah Revenue Streams (Arus Pendapatan) dan Cost Structure (Struktur Biaya). Arus pendapatan menunjukkan uang yang diperoleh, sedangkan struktur biaya menunjukkan biaya-biaya yang harus dikeluarkan. Oleh karena itu dengan Business Model Canvas penulis dapat menganalisa penerapan strategi bisnis pada 
BUMDes-Mart Berkah serta faktor-faktor yang mempengaruhi Business Model Canvas pada BUMDes-Mart Berkah.

\section{METODE PENELITIAN}

Penelitian ini menggunakan metode kulitatif dengan pendekatan deskriptif. Metode penelitian kualitatif digunakan karena peneliti dimana peneliti adalah sebagai instrumen kunci, pengambilan data dilakukan secara purposive dan snowball dengan informan. Teknik pengumpulan dengan triangulasi (gabungan), analisis data bersifat induktif/kualitatif dan menekankan makna dari pada generalisasi data. Data yang digunakan dalam penelitian ini, yaitu data primer diperoleh melalui wawancara dan observasi, dan data sekunder diperoleh melalui literatur ilmiah yang telah diterbitkan sebelumnya seperti buku dan jurnal, adapula data sekunder yang diperoleh melalui media massa yaitu internet. Proses yang dilakukan peneliti dalam penelitian ini yaitu: wawancara, observasi dan dokumentasi.

\section{HASIL DAN PEMBAHASAN Value Proposition (Proposisi Nilai)}

Konsumen BUMDes-Mart Berkah adalah setiap orang pengguna produk (barang dan/atau jasa) yang tersedia di dalam masyarakat Desa Jatimulyo untuk kepentingan diri sendiri, keluarga dan orang lain, bahwa awal mula muncul ide pendirian BUMDes-Mart ini berawal dari melihat warga/masyarakat desanya yang ingin mencari kebutuhan seharihari namun harus menempuh jarak +- $12 \mathrm{Km}$ dari Desa ke kota kecamatan. Maka muncul lah ide ini, yang mana atas kehadiran BUMDesMart ini untuk mempermudah masyarakat belanja sehari-hari dengan harga grosir. Selain itu tujuan pembelian produk ini tidak hanya untuk kebutuhan sendiri namun bisa saja untuk dijual kembali atau diperdagangkan lagi, disebut pengecer atau distributor.

$$
\text { Dengan }
$$

konsumen/masyarakat

demikian, memang membutuhkan tempat untuk membeli berbagai macam kebutuhan sehari-hari sementara jarak ke pasar terdekat sangat jauh. Dengan adanya kehadiran BUMDes-Mart berkah Desa Jatimulyo ini mampu memenuhi kebutuhan yang dihadapi konsumen/masyarakat berada di Desa Jatimulyo dan Desa yang berada disekitarnya yakni Desa Karang Anyar dan Desa
Bengabing dengan harga penjualan yang sama seperti pesaingnya/grosir.

\section{Customer Segment (Segmen Pasar)}

BUMDes-Mart Berkah Desa Jatimulyo memiliki sekelompok orang atau organisasi yang berbeda-beda yang hendak dijangkau dan dilayani (segmen pasar). Segmen pasar mengacu pada pertanyaan "untuk siapa nilai diciptakan?" dan "siapa konsumen/masyarakat atau pelanggan yang paling penting dalam BUMDes-Mart?". Hal ini untuk mengetahui atau mengenal pelanggan merupakan cara paling mudah menentukan segmen pasar pada BUMDes-Mart Berkah.

Segmen pasar pada BUMDes-Mart Berkah ini mengarahkan kepada Geographic (daerah/wilayah) merupakan hal yang menjadi utama, setelah itu baru dilihat dari Demographic (karakteristik,pekerjaan,dan tingkat ekonomi). Hal ini merupakan keunggulan dari pada pendiran BUMDes-Mart yang mana sasaran pembelinya adalah masyarakat yang berada di Desa Jatimulyo dan Desa yang berada disekitarnya yakni Desa Karang Anyar dan Desa Bengabing.

\section{Customer Relationship (Hubungan dengan Konsumen)}

Setiap perusahaan atau organisasi yang sukses pasti berhasil menjalin hubungan yang baik dengan para konsumen/masyarakat atau pelanggannya. Pengelola BUMDes-Mart Berkah harus mampu mengidentifikasi jenis hubungan dengan konsumen/masyarakat yang diharapkan dibangun dan dijaga.

Adapun hubungan yang tecipta atau terbangun pada BUMDes-Mart Berkah yakni hubungan jangka panjang dimana hubungan yang mendalam antara konsumen/masyarakat dan BUMDes-Mart Berkah. Hal ini terlihat dari berinteraksi dalam jual-beli dengan konsumen secara berulang-ulang. BUMDes-Mart Berkah dapat membangun hubungan kepada konsumen/masyarakat secara pribadi yakni Konsumen/masyarakat berkomunikasi dengan BUMDes-Mart untuk memproleh bantuan selama maupun proses transaksi yang dilakukan.

Strategi awal yang dilakukannya untuk mendapatkan konsumen dengan cara menghimbau pada saat acara perwiritan kepada kepala dusun yang ada di Desa Jatimulyo untuk mengajak warganya untuk 
berbelanja di BUMDes-Mart Berkah. Sehingga BUMDes-Mart Berkah ini bisa di ramaikan oleh masyarakat sekitar, yang mana BUMDes-Mart Berkah ini merupakan milik warga Desa bukan milik swasta.

\section{Channel (Cara Menjangkau Konsumen)}

Sebuah usaha dapat memilih dan menentukan cara yang terbaik untuk mendapatkan konsumen/masyrakat baik dengan menggunakan Channel milik sendiri atau dengan bekerjasama dengan Patner Channel ataupun dapat menggabungkan keduanya.

BUMDes-Mart Berkah merupakan usaha yang memanfaatkan tempat kosong yakni bekas koperasi hal ini diungkapkan oleh Bpk. Suyatno Kepala Desa Jatimulyo sebagai Komisaris BUMDes tidak ada pengurangan biaya sewa setiap tahunnya. Namun diawal modal ada dilakukan renovasi gedung kosong bekas koperasi tersebut, untuk menciptakan fasilitas yang memadai dan sedikit biaya. Bpk. Supariyo selaku Direktur BUMDes mengatakan bahwa dalam menjangkau konsumen/masyarakat untuk membeli di BUMDes-Mart Berkah dengan cara memanfaatkan media sosial yakni Facebook yang mana akun nya bernama Desmart Berkah.

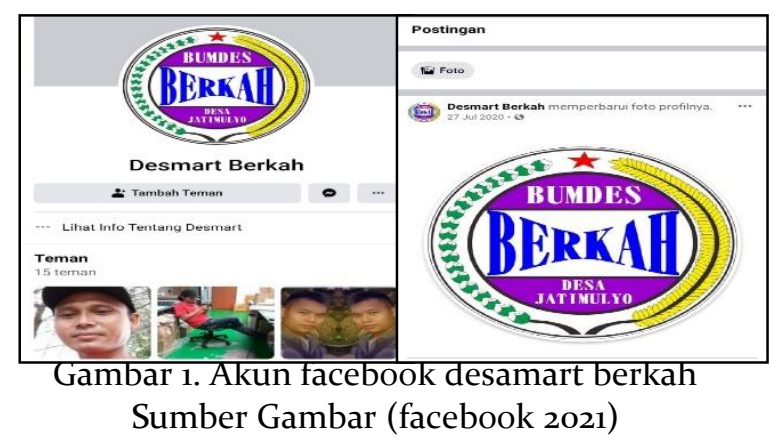

Pada saat peneliti melihat dan memeriksa akun tersebut hasil yang didapatkan tidak sesuai dengan apa diharapkan yakni tidak ada sama sekali postingan yang mengenai penjualan. Hal ini sebenarnya harus ditinjau lagi oleh pengelola BUMDes-Mart Berkah agar sesegara mungkin untuk memperbaikinya. Pada kondisi saat ini seharusnya BUMDes-Mart Berkah memanfaatkan teknologi yang ada, dimana facebook merupakan salah satu media sosial yang bisa digunakan untuk mencari sasaran konsumen/pelanggan dengan tanpa biaya yang harus dikeluarkan. konsep dan perangkat lunak yang membantu manajer memfasilitasi keputusan strategis bisnis di lingkungan yang sulit ini masih langka. Tidak ada alat perangkat lunak yang berguna untuk menilai, memahami, mengukur, mengubah, berkomunikasi atau bahkan mensimulasikan model bisnis (Osterwalder, 2004)

\section{Key Aktivities (Aktifitas Utama)}

Aktivitas utama merupakan suatu kebutuhan untuk menjalankan bisnis model perusahaan termasuk bagaimana cara perusahaan untuk menyelesaikan permasalahan yang ada di dalamnya. Menurut Osterwalder \& Pigneur (2010) Aktivitas utama dapat dikategorikan sebagai berikut produksi, pemecahan permasalahan, dan program/jaringan.

Setiap bisnis atau usaha pasti menjalankan kegiatan utama agar menghasilkan barang atau jasa untuk konsumen/masyarakat dengan tujuan menghasilkan uang bagi perusahaan. Begitu pula dengan BUMDes-Mart Berkah. Kegiatan utama itu disebut sebagai aktivitas utama.

Pekerjaan atau aktivitas yang utama dilakukan pada BUMDes-Mart Berkah ini adalah menjual kebutuhan sehari-hari seperti sembako. Dari penjualan tersebut barang yang sering dibeli oleh konsumen/masyarakat berupa minyak, beras dan gula. Selain penjualan sembako ada kami ada melakukan transaksi tarik tunai, transfer, pembayaran PLN, BPJS dan pembelian pulsa.

Oleh karena itu, BUMDes-Mart Berkah menjalankan kegiatan utama agar menghasilkan uang bagi usaha/bisnis yakni berupa menjual kebutuhan sehari-hari. Selain aktivitas utama, tentu saja BUMDes-Mart Berkah menjalankan beberapa kegiatan atau aktivitas tambahan seperti transaksi tarik tunai, transfer, pembayaran PLN, BPJS dan pembelian pulsa. Pengelola BUMDes-Mart Bekrah harus berfokus pada aktivitas utama tanpa mengabaikan aktivitas tambahan karena melalui aktivitas utama BUMDes-Mart dapat memberikan layanan yang menghasilkan pendapatan.

\section{Key Resource (Sumber Daya Utama)}

Setiap bisnis pasti memerlukan sumber daya utama dalam melakukan kegitan utama dalam rangka menghasilkan barang atau jasa untuk konsumen/masyarakat dengan tujuan 
untuk menghasilkan uang bagi perusahaan. Begitu pula pada BUMDes-Mart Berkah yang memerlukan sumber daya utama. Setiap perusahaan memiliki serta menggunakan sumber daya utama agar bisa menjalankan aktivitas utama. Sumber daya yang digunakan tergantung pada proposisi nilai, saluran distribusi, hubungan konsumen, aliran pendapatan, dan lain-lain.

Tenaga kerja yang berada di dalam operasional BUMDes-Mart Berkah ini berjumlah 3 orang yang terdiri dari 2 laki-laki dan 1 perempuan. Karyawan BUMDes-Mart Berkah ini merupakan penduduk asli Desa Jatimulyo. Hal ini merupakan tujuan pendirian BUMDes yaitu membuka lapangan kerja kepada masyarakat setempat, selain mencari keuntungan dari pendapatan penjualan tersebut.

Dalam membangun bisnis/usaha, modal merupakan faktor utama. Besar kecilnya modal akan berdampak pada bentuk bisnisnya. Tanpa dukungan modal, bisnis tidak akan berjalan. Namun jika bisnis/usaha akan berjalan kalau keuangan yang terjadi di dalamnya harus terlihat transparan dan jelas untuk mengurangi resiko kecurangan pada BUMDes-Mart Berkah. Pendirian BUMDes-Mart Berkah ini menggunakan modal dari APBDesa Jatimulyo.

\section{Key Patnership (Jaringan Pemasok dan Rekanan)}

Agar sukses berbisnis, BUMDes-Mart tidak bisa sendirian karena harus bekerja sama dengan banyak pihak lainnya. Pengelola BUMDes-Mart harus menentukan apa bisnis BUMDes-Mart memerlukan investor bagi permodalan dana dan apa perlu membuat perjanjian kerja sama dengan distributor. Menggandeng mitra yang melengkapi kemampuan yang dimiliki untuk meningkatkan keberhasilan bisnis/usaha BUMDes-Mart Berkah.

Ada kerjasama yang dijalin oleh BUMDesMart Berkah kepada mitra yaitu distributor dalam bahan pokok, kilang padi "jaya", gudam garam air, masyarakat setempat (kripik, roti ketawa, dll), Bank BRI, Bank Mandiri, dan Bank BNI.

\section{Cost Struktur (Struktur Biaya)}

Semua hal yang dilakukan dari point 1 sampai point 7 membutuhkan biaya. Oleh karna itu, penulis melakukan wawancara kepada informan untuk melihat secara seksama dan melihat usaha/bisnis BUMDes-Mart itu menguntungkan atau tidak.

Pengeluaran BUMDes-Mart Berkah pada tahun 2020 yakni pembangian berdasarkan AD/ART BUMDes Berkah adalah $37 \%$ Gaji/insentif pengurus, $5 \%$ Komisaris, $8 \%$ Pengawas, 25 \% Pendapatan Asli Desa, dan 25 $\%$ Operasional.

Tabel 1. Pembagian berdasarkan AD/ART BUMDes Berkah tahun 2020

\begin{tabular}{lll}
\hline No & Uraian & Jumlah \\
\hline 1 & 37\% Gaji / Insentif & Rp. \\
& $5 \%$ Komisaris & Rp. 1.687.066.6.- \\
2 & $8 \%$ Pengawas & Rp. 2.699.306.56.- \\
3 & $25 \%$ Pendapatan & Rp. 8.435.333.- \\
4 & Asli Desa & Rp. 8.345.333.- \\
5 & 25\% Operasional & Rp. 33.741.332.- \\
\hline Total & &
\end{tabular}

Berdasarkan tabel diatas Pembagian berdasarkan AD/ART BUMDes Berkah tahun 2020 yakni 37 \% gaji / insentif sebesar Rp. 12.484.292.84.- per tahun 2020 di bayarkan kepada karyawan BUMDes-Mart Berkah sebanyak 3 orang, 5 \% Komisaris sebesar Rp. 1.687.066.6.- per tahun kepada Kepala Desa, 8 \% Pengawas sebesar Rp. 2.699.306.56.- per tahun kepada 3 orang pengawas, $25 \%$ Pendapatan Asli Desa sebesar Rp. 8.435.333.per tahun kepada masyarakat Desa Jatimulyo dalam bentuk pembelian tikar untuk perwiritan, untuk anak yatim piatu (Sosial), 25 \% Operasional sebesar Rp. 8.345.333.- per tahun untuk mengatasi barang yang kurang/terpakai oleh pengelola dan biaya transportasi.

Dengan demikian, kehadiran BUMDesMart Berkah ini juga memperluas kesempatan kerja baru untuk warga desa. Dampak lanjutan dari semakin luasnya kesempatan kerja tersebut, pada akhirnya dapat meningkatkan pendapatan warga desa sehingga terjadi kesejahteraan warga desa.

Oleh karena itu, BUMDes-Mart Berkah yang dijalankan menyerap tenaga kerja lokal dan menggairahkan kehidupan ekonomi desa. Selain memperhitungkan keuntungan finansial dalam rangka peningkatan Pendapatan Asli Desa (PAD) yang memperkuat kemampuan pembiayaan sosial kepada masyarakat desa jatimulyo. 


\section{Revenue Stream (Aliran Pendapatan)}

Mengembangkan

bisnis

atau

mengembangkan usaha yang ada di dalam unit usaha BUMDes memerlukan keberanian dan perencanaan, tetapi juga ada perhitungan bisnis yang matang sehingga resiko bisnis apapun yang muncul dapat dikelola dengan baik oleh unit usaha BUMDes.

Keuntungan BUMDes-Mart Berkah berasal dari penjualan kebutuhan pokok sehari-hari kepada konsumen/masyarakat adapun jumlahnya yaitu Rp. 33.741.832.00pada tahun 2020, hal ini dijelaskan pada gambar 4.3. bagaimana kondisi pendapatan perbulan BUMDes-Mart Berkah pada tahun 2020.

Tabel 2. Pendapatan BUMDes-Mart Perbulan tahun 2020

\begin{tabular}{lll}
\hline No & Bulan & Pendapatan Bersih \\
\hline 1 & Januari & Rp.2.978.000.00- \\
2 & Februari & Rp.2.663.000.00- \\
3 & Maret & Rp.3.345.500.00- \\
4 & April & Rp.3.135.094.00- \\
5 & Mei & Rp.2.288.795.00- \\
6 & Juni & Rp.3.331.471.00- \\
7 & Juli & Rp.3.006.000.00- \\
8 & Agustus & Rp.3.290.972.00- \\
9 & September & Rp.3.300.000.00- \\
10 & Oktober & Rp.1.904.000.00- \\
11 & November & Rp.2.150.500.00- \\
12 & Desember & Rp.2.348.500.00- \\
\hline Total & & Rp.33.741.832.00- \\
\hline
\end{tabular}

Sumber : Peneliti 2020

Bersarkan tabel 2 pendapatan BUMDesMart pada tahun 2020, pendapatan perbulan yang terbesar yakni bulan Maret sebanyak Rp.3.345.500.00- dan paling sedikit pada bulan Oktober Rp.1.904.000.00-. Dengan demikian, pada situasi COVID-19 pada tahun 2020 yang mana awal muncul di Indonesia di bulan maret tidak ada penuruanan terhadap jual beli di BUMDes-Mart berkah melihat angka pendapatan perbulannya yang cukup stabil.

\section{Faktor-Faktor yang mempengaruhi Penerapan Strategi Business Model Canvas pada BUMDes-Mart Berkah}

David (2004) Manajemen strategis adalah seni dan ilmu penyusunan, penerapan, dan pengevaluasian keputusan-keputusan, manajemen strategis berfokus pada proses penetapan tujuan organisasi, pengembangan kebijakan dan perencanaan untuk mencapai sasaran, serta mengalokasikan sumber daya untuk menerapkan kebijakan dan merencanakan pencapaian tujuan organisasi. Dalam penelitian pada BUMDes-Mart Berkah ada 2 (dua) yang mempengaruhi Penerapan Strategi Business Model Canvas yaitu Customer Segments (segmen pasar) dan finansial yang terdiri dari Cost Structure (Pengeluaran) dan Revenue Stream (Pendapatan).

Pada Customer Segments (segmen pasar) dimana BUMDes-Mart Berkah mengarahkan kepada Geographic (daerah/wilayah) merupakan hal yang menjadi utama, setelah itu baru dilihat dari Demographic (karakteristik, pekerjaan, dan tingkat ekonomi). Hal ini dirasakan oleh masyarakat dengan kehadiran BUMDes-Mart ini mampu menjawab apa yang dihadapi atau permasalahan yang ada pada masyarakat desa untuk membantu dalam memenuhi kebutuhannya.

Penerapan strategi menggunakan Business Model Canvas pada BUMDes-Mart Berkah dipengaruhi oleh finansial yakni Cost Structure (Pengeluaran) dan Revenue Stream (Pendapatan). Pada tahun 2020 BUMDes-Mart Berkah mendapatkan hasil keuntungan finansial sebanyak Rp. 33.741.832.00- dan memberikan kontribusi untuk PAD (Pendapatan Asli Desa) sebanyak Rp. 8.435.333.-. Oleh karena itu, BUMDes-Mart Berkah secara finansial dapat dikatakan menguntungkan.

Hal ini sependapat dengan penelitian Dewobroto (2013) menjelaskan Business Model Canvas dapat menjadi tools yang sederhana guna menghasilkan alternatif strategi perusahaan yang berujung pada kelayakan finansial. Ada persamaan dalam penelitian Saputra (2016) mengatakan bahwa Business Model Canvas dapat digunakan dengan baik oleh bisnis ritel, menandakan bahwa Business Model Canvas dapat diterapkan di berbagai jenis usaha. dan menjadi alternatif untuk menuju finansial yang sehat.

Dengan demikian, Kehadiran BUMDesMart Berkah dapat mengatasi permasalahan yang ada di masyarakat Desa Jatimulyo untuk memenuhi kebutuhan sehari-hari tanpa menempuh jarak yang cukup jauh dan secara finansial kehadiran BUMDes-Mart Berkah ini menguntungkan.

Todaro (2006) mengemukakan bahwa sedikitnya pembangunan harus memiliki tiga tujuan yang satu sama lain saling terkait yaitu: 1) Meningkatkan ketersediaan dan 
memperluas distribusi barang kebutuhan dasar seperti makanan, perumahan, kesehatan, dan perlindungan kepada seluruh anggota masyarakat. 2) Mencapai kualitas hidup yang bukan hanya untuk meningkatkan kesejahteraan secara material, melainkan juga untuk mewujudkan kepercayaan diri dan kemandirian bangsa. Aspek ini meliputi peningkatan pendapatan, penyediaan lapangan kerja, pendidikan dan budaya serta nilai kemanusiaan. 3) Memperluas kesempatan ekonomi dan sosial bagi individu dan bangsa melalui pembebasan dari perbudakan dan ketergantungan pada orang atau bangsa lain serta pembebasan dari kebodohan dan penderitaan. Dapat dikatakan bahwa proses pembangunan dapat diupayakan kearah yang lebih positif serta lebih maju dari pada sebelumnya. Dalam membangun kearah yang lebih maju harus di dukung oleh strategi yang tepat sesuai dengan sasaran dalam penerapannya.

Badan Usaha Milik Desa (BUMDes) merupakan lembaga usaha desa yang dikelola oleh masyarakat dan pemerintah desa dalam upaya memperkuat perekonomian desa, dibentuk berdasarkan kebutuhan masyarakat dan potensi desa yang mana Desa Jatimulyo mencari solusi bagi masyarakatnya untuk mencari kebutuhan sehari-hari namun harus menempuh jarak +- $12 \mathrm{Km}$ dari Desa ke kota kecamatan, maka muncul lah ide, yang mana kehadiran BUMDes-Mart Berkah ini untuk mempermudah masyarakat belanja sehari-hari dengan harga grosir. Badan Usaha Milik Desa (BUMDes) merupakan bentuk kelembagaan desa yang memiliki kegiatan menjalankan usaha ekonomi atau bisnis untuk memperoleh manfaat yang berguna bagi kesejahteraan masyarakat desa. Desa Jatimulyo mendirikan Badan Usaha Milik Desa (BUMDes)- Mart Berkah bukan semata-mata mencari keuntungan ekonomis atau laba, tapi juga manfaat sosial (pembelian tikar untuk perwiritan,membantu anak yatim piatu) dan manfaat non ekonomi lainnya (penyediaan lapangan kerja dan kepuasan kepada karyaawan). Hal ini yang akan menjadikan BUMDes-Mart Berkah menuju kearah yang profesional dalam mengelola dan mandiri.

Terobosan yang sangat strategis dalam bisnis ini adalah usaha ini dilakukan oleh sekelompok orang atau masyarakat yang terdiri dari dalam suatu organisasi dimana lebih baik lagi jika perhimpunan, perkumpulan atau kelompok itu hidup dalam satu area yang sama seperti hal desa jatimulyo, maka hal ini menjadi salah satu pendukung berdirinya BUMDes-Mart Berkah dimana BUMDes adalah suatu lembaga yang paling strategis mengembangkan usaha minimarket.

BUMDes-Mart Berkah memilik sasaran target pembeli Customer Segments (segmen pasar) yang jelas alias kelompok orang yang dibidik sebagai calon pembeli itu bakal lebih mudah didapatkan karena mereka berada di satu area yang mudah dijangkau. Inilah yang membuat minimarket milik BUMDes-Mart Berkah memiliki keunggulan yang tak bisa disaingi. Karena BUMDes-Mart Berkah adalah milik warga desa dan bukan milik perorangan, kepemilikan bersama inilah sebuah modal sosial yang menjadikan potensi awal BUMDesMart Berkah Desa Jatimulyo.

\section{SIMPULAN}

BUMDes-Mart Berkah memerlukan beberapa perbaikan yaitu penambahan pada 3 (tiga) element, yaitu Customer Relationship (Hubungan Konsumen) pada element ini ditambahkan media sosial (WA, line, instagram, facebook, dll), membuat bazzar promosi, brosur promosi, website, dan kartu member untuk pelanggan tetap, Key Resource (Sumber Daya Utama) ditambahkan SDM sebagai petugas kebersihan, Channel (Cara Menjangkau Konsumen) ditambahkan brosur dan media social yang umum digunakan seperti facebook, Instagram.

Faktor-faktor yang mempengaruhi penerapan strategi Business Model Canvas Pada BUMDes-Mart Berkah yaitu Customer Segments (segmen pasar) dan finansial yang terdiri dari Cost Structure (Pengeluaran) dan Revenue Stream (Pendapatan). Customer Segments (segmen pasar) dari BUMDes-Mart Berkah adalah menjangkau kepada Geographic (daerah/wilayah) merupakan hal yang menjadi utama, setelah itu baru dilihat dari Demographic (karakteristik, pekerjaan, dan tingkat ekonomi). Finansial dari BUMDes-Mart Berkah adalah mellihat dari Cost Structure (Pengeluaran) dan Revenue Stream (Pendapatan), pada tahun 2020 BUMDes-Mart Berkah mendapatkan hasil keuntungan finansial sebanyak Rp. 33.741.832- dan memberikan kontribusi untuk Pendapatan Asli Desa (PAD) sebanyak Rp. 8.435.333-. Oleh 
karena itu, BUMDes-Mart Berkah secara finansial dapat dikatakan menguntungkan.

\section{UCAPAN TERIMAKASIH}

Peneliti mengucapkan terima kasih kepada pihak-pihak yang telah membantu terlaksananya penelitian ini yaitu: Dekan Fakultas Ilmu Sosial dan Ilmu Politik Pasca Sarjana Universitas Sumatera Utara, yang telah menugaskan peneliti dalam melaksanakan penelitian ini.

\section{DAFTAR PUSTAKA}

Adhitya, W.R., Sari, E.P., (2019). Graber: Studi Peluang Bisnis Alternatif Mahasiswa di Kota Medan. Journal of Education, Humaniora and Social Sciences (JEHSS). 2 (2): 254-270.

David, F.R. (2004). Manajemen Strategis: Konsepkonsep (Edisi Kesembilan). PT Indeks Kelompok Gramedia.

Dewobroto, W.S. (2013). Penggunaan Business Model Canvas Sebagai Dasar Untuk Menciptakan Alternatif Strategi Bisnis Dan Kelayakan Usaha. Jakarta: Universitas Trisakti.

Kartiasih, F (2019). Inflasi dan Siklus Bisnis Politik di Indonesia. JPPUMA: Jurnal Ilmu Pemerintahan dan Sosial Politik UMA (Journal of Governance and Political Social UMA) (2): 102-110

Lindiawati, I., Harahap, H., \& Mardiana, S. (2021). Analisa Strategi E-Marketing Dinas Koperasi Ukm Kota Medan Terhadap Ukm Binaan Di Tengah Pandemi Covid-19 Tahun 2020. Strukturasi: Jurnal Ilmiah Magister Administrasi Publik, 3(1), 14-29. doi:https://doi.org/10.31289/strukturasi.v3 i1.521

Osterwalder, A. (2004). The Business Model Ontology a Proposition in a Design Science Approach. Thesis, University of Lausanne.

Osterwalder, A., \& Pigneur, Y. (2010). Business Model Generation: A Handbook for Visionaries, Game Changers, and Challengers. New York: John Wiley \& Sons, Inc.

Pambudi, R. (2015). Business Model Canvas: Uji Kelayakan pada Bisnis Ritel (Studi Pada Toko Basic Computer). Lampung: Universitas Lampung

Peraturan Menteri Desa, Pembangunan Daerah Tertinggal, dan Transmigrasi Nomor 4 Tahun 2015 Tentang Badan Usaha Milik Desa.

Peraturan Pemerintah Nomor 11 Tahun 2019 tentang Perubahan Kedua Atas Peraturan
Pemerintah Nomor 43 Tahun 2014 Tentang Peraturan Pelaksanaan Undang-Undang Nomor 6 Tahun 2014 Tentang Desa.

Peraturan Pemerintah Nomor 11 Tahun 2021 tentang Badan Usaha Milik Desa (BUMDes).

Peraturan Pemerintah Nomor 43 Tahun 2014 Tentang Peraturan Pelaksanaan UndangUndang No 6 Tahun 2014 Tentang Desa.

Putri, F.F.T. (2015). Analisis Inovasi Model Bisnis Menggunakan Pendekatan Busines Model Canvas. Jurnal Universitas Telkom. Bandung.

Ramadana, C.B., Ribawanto, H., \& Suwondo. (2013). Keberadaan Badan Usaha Milik Desa (BUMDes) sebagai Penguatan Ekonomi Desa (Studi di Desa Landungsari, Kecamatan Dau, Kabupaten Malang). Jurnal Administrasi Publik (JAP), 1(6), 1068-1076.

Saputra, S. (2016). Uji Kelayakan Pada Bisnis Ritel Toko Dunia Parfum Menggunakan Business Model Canvas. Lampung: Universitas Lampung.

Setkab, (2019). Berharap Disalurkan Januari 2020, Presiden Jokowi Minta Penggunaan Dana Desa Utamakan Program Padat Karya. htttps://setkab.go.id/berharap-disalurkanjanuari-2020-presiden-jokowi-mintapenggunaan-dana-desa-utamakan-programpadat-karya/.

Siagian, S.P. (2008). Manajemen Sumber Daya Manusia

Siregar, O., \& Selwendri, S. (2020). Achievement of The Target Market Through Business Model Canvas in Small and Medium Enterprises (Smes). Journal of Education, Humaniora and Social Sciences (JEHSS), 3(2), 286-293. doi:https://doi.org/10.34007/jehss.v3i2.215

Stefan, S., \& Bednar, R., (2014). Analysis of Business Model. Journal of Competitiveness. University of Economics in Bratislava

Taufiq, M., Rahmatunnisa, M., \& Rizkiyansyah, F. (2020). The Prosperous Justice Party of Bandung City and its Mix Strategy Marketing in the 2019 Election. JPPUMA: Jurnal Ilmu Pemerintahan dan Sosial Politik UMA (Journal of Governance and Political Social UMA), 8(2), 142-153. doi:https://doi.org/10.31289/jppuma.v8i2.3 698.

Todaro. (2007). Pembangunan Ekonomi di Dunia Ketiga. Jilid I, Edisi Keenam. Jakarta: Erlangga.

Undang-Undang Nomor 23 Tahun 2014 Tentang Pemerintahan Daerah.

Undang-Undang Nomor 6 Tahun 2014 Tentang Desa. 